\title{
Discourse as a Strategic Resource ${ }^{1}$
}

\author{
Cynthia Hardy \\ Department of Management \\ Faculty of Economics \& Commerce \\ University of Melbourne \\ Parkville \\ Victoria, Australia 3052 \\ Tel: 61-3-9344-5344 \\ Fax: 61-3-9349-4292
}

Email: C.Hardy@ecomfac.unimelb.edu.au

\author{
Ian Palmer \\ School of Management \\ Faculty of Business \\ University of Technology, Sydney \\ PO Box 123 Broadway \\ NSW, Australia 2007 \\ Tel: 61-2-9514-3606 \\ Fax: 61-2-9514-3602 \\ Email: I.Palmer@uts.edu.au
}

\author{
Nelson Phillips \\ Faculty of Management \\ McGill University \\ 1001 Sherbrooke West \\ Montreal, Canada H3A 1 G5 \\ Email: Phillips@management.mcGill.ca
}

$6^{\text {th }}$ September, 1999

Revised version for consideration by the Special Issue of Human Relations 


\title{
Discourse as a Strategic Resource
}

\begin{abstract}
In this paper, we outline a model of how discourse can be mobilized as a strategic resource. The model consists of three circuits. First, in circuits of activity, individuals attempt to introduce new discursive statements, through the use of symbols, narratives, metaphors, etc. aimed at evoking concepts to create particular objects. These activities must intersect with circuits of performativity. This occurs when, for example, concepts are contextually embedded and have meaning for other actors; when symbols, narratives and metaphors possess receptivity; and when the subject position of the enunciator warrants voice. Third, when these two circuits intersect, connectivity occurs as the new discursive statements "take". Using an illustrative example of an international NGO operating in Palestine, we show how an individual brought about strategic change by engaging in discursive activity.
\end{abstract}

Key Words: Critical discourse analysis, strategy, organization theory 


\section{Introduction}

Traditionally, the literature on strategy and the literature on discourse have largely ignored each other. Recently, however, writers have started to examine the links between the two, as a result of which two divergent views have emerged. One stream of research tends to treat discourse as an infinitely malleable variable that can be used to produce any desirable strategic outcome (e.g., Eccles \& Nohria, 1993; Hamel \& Prahalad, 1994). However, this work remains largely uninformed by the wider literature on discourse theory. Another body of work suggests there is little scope to manipulate the discourse of strategy, which traps academics and practitioners alike (e.g., Knights \& Morgan, 1991; Inkpen \& Choudhury, 1995). While this work is theoretically informed by the wider discourse literature, it has largely ignored the managerial implications of discursive approaches to strategy. We attempt to bridge these approaches by using critical discourse theory to build a model that shows how discourse can be used as a resource by individuals in their efforts to enact strategy.

We suggest that it is possible for individuals to engage in discursive activity and to access different discourses to generate new meanings that help — or hinder — the enactment of particular strategies. However, such use of discourse is not infinitely pliable. Strategic actors cannot simply produce a discourse to suit their immediate needs and, instead, must locate their discursive activities within a meaningful context if they are to shape and construct action. As a result, a complex relationship emerges as the activities of actors shape discourses, while those discourses also shape the actions of those actors. Consequently, if we want to 
explain how discourses operate, we must examine the broader context in order to ascertain the scope that it provides for action, as well as the limits it places on action.

In this paper, we explore how discursive action is embedded within broader frameworks of understanding, communication and interaction. We develop a model of discourse as a strategic resource and, using an illustrative example, show how an individual engaged in discursive activity attempts to bring about strategic change. We explore this activity in detail to identify both its scope and its limitations, and to suggest the components linked to the successful use of discourse in a strategic context.

This paper is organized as follows. First, we review the strategy literature that draws on discursive approaches; we then examine work on discursive aspects of organizations. Second, we develop a model of discourse as a strategic resource. Third, we describe the case study on which this paper is based. Finally, we show how one actor attempted to intervene in processes of discursive production for strategic purposes and we draw some conclusions regarding how actors can use discourse as a strategic resource.

\section{Strategy and Discourse}

In this section, we discuss some of the more recent work on the discursive aspects of strategy. We then examine discursive approaches to understanding organizations. 


\section{Discursive Approaches to Strategy}

The strategy literature has been divided into a number of different approaches. For example, Chaffee (1985) identified three mental models of strategy. Mintzberg (1990) classified the literature into ten schools of thought. Zan (1990) differentiates between four different types of strategy. Whittington (1993) talks of four strategic perspectives. Rouleau \& Séguin (1995) distinguish four forms of strategic discourse. Palmer \& Hardy (2000) present six different approaches to strategy. One relatively recent perspective in the strategy literature is the study of language, rhetoric and narrative (Hatch, 1997). These discursive analyses emphasize strategy as a social and, in particular, a linguistic construction. For example, Eccles \& Nohria (1993: 88) consider strategy to be a particular kind of rhetoric that provides a "common language used by people at all levels of an organization in order to determine, justify, and give meaning to the constant stream of actions that the organization comprises."

Within the discursive perspective, two somewhat divergent approaches can be identified. One approach comprises a theoretical body of work that draws on postmodern insights (Knights \& Morgan, 1991), Giddens' (1981) notion of structuration (Whipp, 1996), narrative theory (Barry \& Elmes, 1997) and critical discourse analysis (Thomas, forthcoming). It sees strategic discourse as a space where language and action serve to constitute each other. Strategic plans, mission statements, academic papers, articles in Fortune or The Economist, strategy taskforces, as well as specific actions or practices, such as acquisitions, restructuring, or selling in overseas markets help to constitute the discourse of 
strategy. Similarly, the way in which research questions are posed, methodologies are selected, and publishing conventions are imposed helps to constitute strategy as a field of inquiry which, since there are interactions between academia and practice (Clegg \& Hardy, 1996), has implications for management practice. Consequently "strategy" — like "the environment" and "the organization" — is a construction, reproduced by a variety of texts and practices, that serves to make sense of the world.

This approach argues that strategy discourse does not simply mirror social reality - it creates it. The way in which we talk about strategy — as well as the way in which we analyze particular actions that we categorize as strategic - have political implications. For example, the top-down conceptualization of strategy embodied in much of the literature helps to reproduce hierarchical relations. Further, it has been argued that most views of strategic management help to constitute a conservative, political ideology centered on profit, managerial power and the reinforcement of existing capitalist relations (Shrivastava, 1986). Strategy's widespread acceptance and association with organizational performance also advantages those groups associated with "performance-related" activities; at the same time, others, such as accountants and human resource managers, strive to make themselves more "strategic" by redefining their work as "performance-related" (Knights \& Morgan, 1991). Within strategic discourse, some subjects - senior managers, academics, business journalists - have a clear mandate to speak and act, while other actors are unheard and invisible. So, by conceptualizing strategy as 
a discursive construction, we can explore its political implications by asking who gets to write and read the story (Barry \& Elmes, 1997).

This approach draws attention to the power of strategy discourse. Today, the term strategy is ever present - in hospitals, universities, governments as well as businesses (Whittington, 1993; Whipp, 1996), even though entrepreneurial capitalists before the 1950's managed well enough without the benefit of this concept (Knights \& Morgan, 1991; Whipp, 1996). Thus the accumulation of texts and practices on the part of researchers and managers in their search for strategy produces a phenomenon from which it has become difficult to escape. Strategy has become so well ingrained in business language that it is commonly accepted as a determinant of success and failure: whether by having a good strategy, a bad strategy, or no strategy. Similarly, Inkpen \& Choudhury (1995) argue that the discovery of strategy is simply an artifact of research conventions and says more about how academics theorize than how firms operate.

A second body of research on the discursive aspects of strategy has adopted a more practical emphasis. For example, drawing on the work of Wittgenstein (1974) on language games, Eccles and Nohria (1993) argue that strategic discourse creates an organizational reality. Strategy represents a form of rhetoric that makes sense of, legitimates and produces certain activities. They suggest that the effective use of strategic language can galvanize organizations into action and, thereby, guarantee financial success. This is achieved by defining powerful core concepts, by providing guidelines for action, and by providing a means for communication. These authors argue, however, that managers must remember that, in adopting the rhetoric of 
strategy, they have simply passed over other rhetorical devices that might have conjured up a different set of actions. Similarly, Hamel \& Prahalad's (1994) work on core competencies and strategic intent also incorporates a number of discursive elements, as does work on strategic identity (Dutton \& Duckerich, 1991; Dutton \& Penner, 1993; Eccles and Nohria, 1993; see Hardy \& Palmer, 1997).

This practice-oriented literature has not exploited much of the literature on discourse theory, primarily conceptualizing strategy as rhetoric. In this regard, strategy making becomes largely the management of meaning. As such, this work is vulnerable to the criticism that it says little about how talk produces action (Palmer \& Dunford, 1996; Hardy, Lawrence, \& Phillips, 1998). Questions concerning how thinking up or, to be more precise - talking up — a new strategy translates into organizational actions remain unanswered. As Mintzberg (1994, p. 281) has already asked: how can an organization transform itself simply by thinking up a new strategy? Conversely, the theoretically oriented literature has drawn explicitly on the wider body of discourse theory, but has largely ignored the managerial applications of a discursive approach to strategy. As a result, we know little about how the discursive aspects of strategy might be managed or the practical implications that might result from such activities.

\section{Discursive Approaches to Organizations}

As van Dijk (1997a) points out, discourse as a field of study is "fuzzy". It encompasses a number of approaches that are informed by a wide variety of disciplines. The role of discourse in organizations is equally difficult to define (Keenoy, Oswick, \& Grant, 1997; Grant, Keenoy, \& Oswick, 1998). Despite 
divergent and sometimes conflicting approaches, it is clear that research on organizational discourse is associated with the study of texts (although what constitutes a text is also a matter of some debate) and their use in particular organizational settings. For the purposes of this study, we follow the work of critical discourse theorists (Fairclough, 1992; Parker, 1992) and define discourses as sets of texts - statements, practices, etc. — which bring an object into being. Thus discursive analysis requires an examination of language, the production of texts and processes of communication, and the interactions between actors in organizational and institutional settings (Grant et al., 1998).

Underlying this approach is the view that discourse plays a role in the social construction of reality (Condor \& Antaki, 1997). Discourse does not merely describe things, it does things (Potter \& Wetherell, 1987; Grant et al., 1998). Discourse is both socially constituted and socially constitutive as it produces objects of knowledge, social identities and relationships between people (Fairclough \& Wodak, 1997). In discourse analysis, "the communicative practices of members are examined for the ways that they contribute to the ongoing (and sometimes rather precarious) process of organizing and constituting social reality" (Mumby \& Clair, 1997, p. 181). Studying discourse is, then, a powerful way to explore processes of organizing and, particularly, the fragility of, and struggles within, organizational life.

Studies of the political effects of discourse examine how it acts as a cultural resource. They reveal how people engage in discursive activity to pursue their plans and projects, how discourses are jointly constructed, and the local or institutional ends that particular discourses serve (Wetherell \& Potter, 1988; Condor \& Antaki, 
1997). While some writers argue that the power effects of discourse are beyond the control of individuals (Condor \& Antaki, 1997), others argue that discursive activity can influence intended outcomes (see Grant et al., 1998). Our approach rests on the latter assumption — that individuals do engage in discursive activity in ways that produce outcomes that are beneficial to them (Hardy et al., 1998). We do not assume that such agency is without limit but, rather, that individuals engage in discursive activity — produce and disseminate various forms of texts — within a larger discursive context (Hardy \& Phillips, 1999). The discourses that comprise this context emanate from struggles between different actors and the accumulation of the activities of many individuals (Phillips \& Hardy, 1997). Therefore, most contexts including organizations - consist of multiple and fragmented discourses that provide actors with choices concerning the discourses on which they draw. In fact, interdiscursivity — drawing on "foreign" discourses can be an important strategy to bring about change (Fairclough, 1992). Thus, individuals engage in discursive activity with particular intentions in mind and may secure preferred outcomes, but they do so against a backdrop of multiple discourses that have complex, far reaching effects that are beyond the control of single individuals.

Discursive activity does not occur in a vacuum. To understand discourses and their effects, we must understand the context in which they arise (Grant et al., 1998). Discourse studies should deal both with the properties of text and talk and with what is usually called the context, that is, the other characteristics of the social situation or the communicative event that 
may systematically influence text or talk. In sum, discourse studies are about talk and text in context. (van Dijk, 1997a, p. 3)

Discursive activity should, then, be studied as a constitutive part of its local and global, social and cultural context (van Dijk, 1997a). Discourses do not "possess" meaning. Instead, their meanings are supported and contested through the production of texts. They are shared and social, emanating out of interactions between the social groups and societal structures in which the discourse is embedded.

It is for this reason we draw on an illustrative case study (described below). In this way, we are better able to situate discourse in a co-constitutive relationship between particular discursive activities and the social structures that frame it.

Discourse is not produced without context and cannot be understood without taking context into consideration ... Discourses are always connected to other discourses that were produced earlier, as well as those which are produced synchronically and subsequently. In this respect, we include intertextuality as well as sociocultural knowledge within our concept of context (Fairclough \& Wodak, 1997, p. 277).

Contexts, like discourses, are not objective - they, themselves, are socially constituted. "They are interpreted or constructed and strategically and continually made relevant by and for participants" (van Dijk, 1997b, p. 16). By studying the larger context and showing how it shaped and was shaped by discursive activity, our study becomes "three dimensional" (Keenoy et al., 1997) as we locate the discourse historically in order to bridge text and context (Fairclough, 1995). 
To conclude this section, our interest lies in how discourse is used as a resource by actors in their attempts to enact their strategic intentions. We are interested in power and agency — the scope for action — as well as the limits of action. To achieve our objectives we will use two devices - a model derived from critical discourse theory and an illustrative case study. Or, to put it more simply, we are interested in "who uses language, how, why and when (van Dijk, 1997a, p. 2).

\section{Discourse as a Strategic Resource}

To understand how discourse acts as a strategic resource, we draw explicitly from critical discourse theory (Fairclough, 1992; 1995; Fairclough \& Wodak, 1997). This approach sees organizations "not simply as social collectives where shared meaning is produced, but rather as sites of struggle where different groups compete to shape the social reality of organizations in ways that serve their own interests" (Mumby \& Clair, 1997, p. 182). We build on a model that has been developed and applied elsewhere (Phillips \& Hardy, 1997; Hardy et al., 1998; Hardy \& Phillips, 1999). Specifically, we argue that discourses create social "reality" through the production of concepts, objects and subject positions, which shape the way in which we understand the world and react to it (Fairclough, 1992; Parker, 1992; Phillips \& Hardy, 1997). When discourse is used as a strategic resource, individuals engage in discursive activities to intervene in these relationships.

First, discourses produce concepts - categories, relationships, and theories — through which we understand the world and relate to one another. Concepts make up what Harré (1979) refers to as the expressive sphere: all of the conceptual ideas that make up our cultural background. They exist solely in the realm of ideas, 
are more or less contested and are culturally and historically situated. Implicit in the production of discursive concepts are ideas of "rightness", what Bakhtin refers to as the "accent" of the concept (Gardiner, 1992, p. 15). In other words, concepts carry with them a moral evaluation that is part of the ongoing discursive accomplishment of the concept. Concepts depend on the ongoing construction of texts for meaning and may, therefore, change dramatically over time and from one situation to another as texts are produced, disseminated, and interpreted by actors in a social situation (Hardy \& Phillips, 1999). Consequently, individuals may engage in discursive activity with the intent of transforming a concept in order to change individual understandings of the world and, hence, how social relations are accomplished (Phillips \& Hardy, 1997).

Second, when concepts are brought into play to make sense of social relations or physical objects, they help to constitute objects by making the material world meaningful. We do not suggest that pre-existing objects are revealed by concepts, but that concepts are often "discursively attached to particular parts of an ambiguous material world; a world that has an ontological status and a physical existence apart from our experience of them" (Hardy \& Phillips, 1999, p. 3). Objects only make sense in terms of the concepts that are applied to them - as concepts change, new objects are produced and, equally importantly, very different practices may be invoked (Phillips \& Hardy, 1997). Discursive activity on the part of individuals may, then, revolve around trying to evoke particular concepts in order to produce different objects. 
Third, subject positions arise as subjects acquire rights to speak in particular discourses, which Potter \& Wetherell (1987) call "warranting voice". Theorists such as Foucault (1972) assert that limited numbers of positions exist within discourses from which individuals can speak and act. To be able to speak within a discourse requires the actor to take up one of the subject positions. Discourse also positions interpreters of a text. In defining and circumscribing positions from which subjects can speak, act, and interpret, discourse captures producers as effectively as participants and audience. Individuals may, then, engage in discursive activity in attempts to secure advantage from particular subject positions or to silence other subjects (Phillips \& Hardy, 1997).

In this way, discourses reproduce and transform institutional structures (Parker, 1992). As Fairclough (1992) notes, discourse theory does not suggest that the "realities" of the social world reside inside people's minds; rather it argues that individuals are confronted with the relations and identities previously constituted in discourse and reified into institutions and practices. "Thus the discursive constitution of society does not emanate from a free play of ideas in people's heads but from a social practice which is firmly rooted in and oriented to real, material social structures" (Fairclough, 1992, p. 66). By intervening in these processes of discursive production, individual actors hope to achieve "real" political effects.

From this discussion, we are able to develop a model of discourse as a strategic resource, which comprises three different circuits (figure 1). For the purposes of clarity, we present them in a linear fashion but it is important to note that the circuits are iterative and overlap. The first circuit comprises discursive activities 
on the part of individuals who are attempting to use discourse strategically. (1) Individuals make discursive statements in their attempts to manage meaning in ways that support their intentions. (2) These statements involve the creation and dissemination of texts, including the introduction of symbols, the creation of narratives, the use of metaphors, the employment of rhetoric, etc. (3) These texts associate particular concepts with certain relations and/or material referents in order to create objects.

\section{INSERT FIGURE 1 ABOUT HERE}

If the circuit of activity is to have a political effect, it must engage other actors. We call this process the circuit of performativity (Lyotard, 1984). (4) This occurs when the concepts evoked in discursive statements are embedded in the larger discursive context - the relevant concepts must have meaning for the individuals at whom they are directed. An individual does not have a free choice in employing concepts and cannot conjure a new object out of thin air. (5) Similarly, the symbols, narratives, metaphors employed by the enunciator must possess receptivity. They must resonate with other actors, otherwise they will fail to convey the meaning intended by the enunciator. (6) In addition, the subject position of the enunciator must warrant voice, otherwise other individuals will simply ignore his or her statements.

If activity and performativity intersect, they create a circuit of connectivity. (7) By this we mean that the new discursive statements "take" (Srivastva \& Barrett, 
1988, p. 54) as concepts are successfully attached to relations and/or material referents and create specific objects in the eyes of other actors. (8) New subject positions and practices also emerge. (9) The accumulation of individual statements and practices influences the context for future discursive activities as prevailing discourses are contested, displaced, transformed, modified or reinforced.

\section{An Illustrative Example: Mère et Enfant ${ }^{2}$}

In this section, we use an example to illustrate the model. We first describe Mère et Enfant and the events that transpired. We then analyze the events according to the model outlined in the previous section.

\section{Mère et Enfant}

Mère et Enfant is an international NGO, based in Europe and funded by a European government. Its charter commits the organization to work on behalf of the neediest of the world's children, regardless of gender, race, nationality or other considerations. It works with children as members of families within the community, rather than as individuals. It emphasizes prevention and education, and is committed to sharing knowledge and to empowering the community it serves. Our interest is in one particular "branch" of Mère et Enfant — Mère et Enfant (Palestine) — which operates in the West Bank and Gaza. It is administered and funded by the larger organization, which derives most of its resources from the government of the European country in which it is based.

To conduct our research, we carried out interviews with the Delegate responsible for the West Bank and Gaza. He is an ex-patriate employee who 
manages 60 individuals employed by Mère et Enfant in this region, all of whom are Palestinian (except for one British nutritionist). He was appointed to this position in 1993. In addition to the Delegate, we interviewed Palestinian managers in the organization, local members of the steering committee, and representatives of other organizations with whom Mère et Enfant worked. We conducted a total of 14 interviews in 1997, which lasted between one and two hours, were semi-structured, recorded and transcribed. The Delegate also made available a range of documentation including memos, organizational newsletters, organizational charts, year-end reports, minutes of meetings, funding proposals, and other documents.

\section{The West Bank and Gaza}

The Gaza strip is a small piece of land (365 square km) occupied by over 800,000 Palestinians, making it one of the most densely populated areas in the world. The Palestinian population growth rate is 4 percent and half the population is under 14 years old. Approximately three-quarters of the Palestinians in Gaza are refugees living in one of eight refugee camps. The West Bank covers an area of 5,500 square $\mathrm{km}$. It is mainly rural with about 400 villages and four major towns. Forty percent of the population are refugees, living in one of twenty refugee camps. The population is estimated to be over one million, half of which are less than 14 years of age. The infant mortality rate is estimated by Palestinians to be 50 deaths per 1,000 live births. Diarrhoea and acute respiratory infections account for more than half of all child deaths in Palestine.

Mère et Enfant has been operating in Gaza and the West Bank for over ten years and its main emphasis in this region is on child nutrition. Its aims to reduce the 
infant mortality rate, especially deaths from diarrhoea and diarrhoeal diseases; to identify and improve the nutritional status of children in the West Bank and Gaza; to offer nutritional rehabilitation to malnourished children; and to raise the level of consciousness of the citizens and professionals about the importance of good nutrition. It treats children directly by providing medical and nutritional services in Hebron (in the West Bank), Gaza and Khan Younis (in the Gaza Strip). It has an outreach program to provide community education and provides training in diarrhoea management, breast feeding, safe weaning, etc. in the community and among health care professions. It conducts research into the nutritional status and food security and other matters related to the health of Palestinian child. It provides information and education to both the public and policy makers about nutrition and poverty.

\section{The Strategy of Localization}

Since the appointment of the Delegate, Mère et Enfant had been in the process of "localizing" its activities in this region. Localization is a process whereby regionally based operations, administered and funded by an international NGO, are transformed into a local NGO. The localized organization typically has a steering committee comprised of representatives from the local community and is ultimately responsible for securing its own funding from a variety of sources on a sustainable basis, although the original donor usually undertakes to continue to provide funding during a transition period. In this way, the localized organization is independent and self-sufficient, providing services demanded by the community in which it operates and competing with other agencies for funds. 
NGOs like Mère et Enfant have engaged in localization strategies in response to an increasingly complex external environment that has given rise to a multiplicity of pressures. First, funds for NGOs are always a scarce resource. For example, the European government that funds Mère et Enfant has cut back on its financial support. Second, major donors, such as the World Bank, are increasingly attracted to the idea of giving money to local NGOs rather than to international agencies. Third, the governments and citizens of "developing" countries are increasingly demanding that international agencies devote more attention to empowerment. Consequently, instead of management practices that perpetuate the dependency relationship between an agency and its "clients", there is a move towards establishing a development relationship in which knowledge and skills are transferred from agency to client. Fourth, global economic and political conditions, which affect the living conditions of children change dramatically and unexpectedly, creating new pockets of need in different parts of the world. If Mère et Enfant continues to use traditional methods of funding, its resources remain largely "locked" into the existing countries that it serves, and cannot be easily switched to meet emerging areas of need. Finally, in addition to these factors that shape Mère et Enfant's global environment, changes in regional politics created an added momentum for localization in the West Bank and Gaza. During the Israeli occupation, the absence of a legitimate Palestinian authority meant that international NGOs played a particularly important role in the area. Following the Oslo peace agreement, the Palestinian National Authority was formed, which indicated its desire to develop and work with local NGOs. 
In many respects, the impetus for localization stems from challenges similar to those perceived by business organizations. In fact, it is an example of how business discourses are permeating the voluntary sector. Mère et Enfant's environment is becoming increasingly competitive and turbulent and its point of reference is ever more global. The localized organization must provide services that are demanded by the "market" and which are sufficiently attractive to secure funding from a variety of donor organizations. Internally, the localized organization must be capable of delivering these services and possess the necessary skills, resources, depth of management and governance structure. Under localization, an organization cannot afford to offer services simply because it always has done so; it is now competing for funds in an increasingly difficult environment. Unless its services are valued and unless it can "add value" where other agencies cannot, the localized organization will not receive the long term funding it needs to survive.

\section{Localization at Mère et Enfant}

Following his appointment in 1993, the Delegate undertook a number of steps to rationalize inappropriate or under-performing services in preparation for localization. As a result, some thirty people lost their jobs over a three-year period. Since some of these services had been problematic — for example, a children's clinic had been closed after finding evidence of negligence towards the children in its care - the reputation of the organization was increased. The remaining services were enhanced and the financial situation was improved. He also established a number of collaborations with other organizations to secure funds, personnel, and equipment and to enhance expertise through training. 
Despite these changes, in late 1996 the organization was still seen by members of both the organization and the community as an international NGO. To be constituted as a legitimate, local NGO in the eyes of the Palestinian medical, political and NGO communities, further changes would be required. Among them was the creation of a steering committee consisting of members of the local political and professional community to take management responsibility for the newly devolved organization. Typically, these are people with the relevant management and clinical expertise and/or political connections. The steering committee planned by the Delegate included the Minister of Health and the Director-General for Primary Care - both of the Palestinian National Authority — as well as other professionals from the Palestinian community.

In September 1996, the Delegate called together a number of individuals whom he felt might become members of the prospective steering committee, although decision making remained under the control of the Delegate, and Mère et Enfant (Palestine) was still part of the larger organization. The following month, the Delegate announced the layoff of 15 employees. The Delegate had originally intended to complete this round of organizational changes before establishing the steering committee. However, a visit from an evaluation team from the European headquarters, which wanted to see evidence of localization, prompted him to move more quickly than he had previously planned in establishing the steering committee.

The announcement of layoffs provoked demonstrations by employees and members of the local community. Although lacking any formal authority, the members of the steering committee met, in the absence of the Delegate, to discuss 
the matter. They felt that that the employees should be reinstated and issued a statement to that effect. The matter then escalated when disaffected employees went to the security forces and made allegations against Mère et Enfant and some of its Palestinian staff members. The security forces then became involved and exerted considerable pressure on two Palestinian managers, calling them in for interrogation and threatening imprisonment and torture unless they reinstated the employees.

By this time, in the eyes of many Palestinians - including the security forces — the organization was now a local NGO with its own steering committee that had recommended reinstatement of the employees. In other words, the international organization had been discursively re-constituted as a local one through the creation of a steering committee, a meeting of that committee, and a statement by that committee. These discursive acts "changed" the organization, particularly in the eyes of powerful external actors, as a result of which the environment also "changed" for outsiders and insiders alike. In other words, the organization "became" a local NGO even though it remained under the formal control of the Delegate and part of the international NGO. As a local NGO, its members were left without the political protection afforded by the status of an international agency, and were immediately subjected to all the norms and controls of the local environment.

In order to protect his employees from further harassment, the Delegate engaged in a number of activities designed to re-establish the status of the organization as an international agency with political connections and financial clout. He sent out a series of memos and letters in October and early November to a range of individuals and organizations, including heads of other NGOs, members of the 
Palestinian National Authority, and members of the security forces, stating the following. "[W]ith immediate effect, the process of localizing its projects in Palestine — that is of handing over the projects of [Mère et Enfant] to new owners and managers is suspended." He also let it be known that "line management responsibility for the projects of [Mère et Enfant] in Palestine will be assumed in totality by the Delegate and through him to [the government of the European country where Mère et Enfant is headquartered and funded]." He disbanded the steering committee to reinforce the statement that the management of the organization did not reside in local hands. He also met with the head of the security forces as well as prominent members of the Palestinian National Authority to consolidate the organization's status as an international NGO.

In taking these actions, the Delegate consistently emphasized the role of European headquarters in the management of the organization. For example, he maintained that the reason why workers were asked to leave the organization was the result of "changes in our working methods [which resulted from] an evaluation of our work by the [European] government and [our headquarters], our two funders." By the end of November, the Delegate had received reassurances from members of the Palestinian National Authority that employees were safe from further intervention by the security forces and the organization once again "became" an international NGO.

\section{Using Discourse as a Strategic Resource}

We can analyze the case of Mère et Enfant using the model presented earlier. In order to simplify the analysis, we focus on the discursive activities of the Delegate 
and their effects, primarily, on individuals outside the organization although, as is clear, there were significant indirect effects on members of the organization.

(1) The Delegate initiated a circuit of discursive activity by making a series of discursive "statements" that the organization was going to be localized. Many of these interventions were interdiscursive in that they introduced a new discourse that of localization - into the organization. (2) For example, he made increasing use of the Arabic translation of Mère et Enfant. He continually wrote about localization in internal reports and in the organization's newsletter. He also set about creating a steering committee consisting of community representatives, which is a widely recognized way of signifying a local NGO. (3) These activities helped to associate the existing organization with a new concept - a local NGO - and thereby create a new object. Previously, the organization had been connected to a different concept — that of an international NGO (figure 2).

\section{INSERT FIGURE 2 ABOUT HERE}

Activity alone does not mean that a new object will necessarily be created since other actors may not make the associations between the organization and the concept. Consequently, we must look rather more deeply at the performativity of these activities — how the Delegate's discursive statements were "received" and why. (4) The concept - the local NGO — was well embedded in this particular context. Many NGOs were localizing at this time and the practice was familiar to individuals inside and outside the organization. Moreover the rhetoric was popular in 
both the wider international domain and the specific region. (5) The steering committee was a commonly recognized symbol among the various actors, including members of the Palestinian community, members of the NGO community and the members of the evaluation team. Similarly, the Arabic version of the organization's name and the various narratives regarding localization written by the Delegate also possessed receptivity. (6) The subject position of the enunciator - the Delegate warranted voice. Someone in his position could make these statements and take these decisions in ways that other members of the organization and the community could not. These factors thus comprised a circuit of performativity - the symbols, concepts, and enunciator "resonated" within the particular context and among the particular actors.

In this example, the circuits of activity and performativity intersected as (7) the discursive statements of the Delegate "took," linking organization and concept in a meaningful connection. (8) This connection resulted in the emergence of new subject positions, such as the members of the steering committee who gained and exercised voice, and practices, including the rather unsavoury actions of the security forces. (9) Accordingly we can see how a new object, consistent with the strategy of localization, was produced in terms of how the organization was perceived and treated by external actors.

The Delegate then engaged in a discursive "counter attack" to address the actions of the security forces and protect his employees from further harassment (figure 3). (1) It represents a second round of discursive activity aimed at (2) reattaching the organization to the concept of an international NGO. (3) The memos, 
faxes and meetings communicated a new (or, rather, old) narrative of an international NGO governed from Europe, while the disbanding of the steering committee removed a symbol associated with a local NGO. These discursive statements initiated a circuit of activity designed to manage the meaning of the organization's status by re-associating it with the concept of an international NGO.

(4) This concept had not been displaced as the idea of an international NGO still had meaning in the Palestinian context, as well as in the wider European context to which the Delegate consistently referred in his communications. (5) The Delegate still had the authority of his position and therefore continued to warrant voice; and (6) the symbols he employed (disbanding the steering committee) and narratives he constructed (the story of the role of the European headquarters) also continued to possess receptivity.

\section{INSERT FIGURE 3 ABOUT HERE}

(7) These discursive (re)statements of an international NGO "took" as (8) the new subject position — the members of the steering committee — disappeared and the practices instituted by the security forces stopped. Reconstructing Mère et Enfant as an international NGO reinstated the relationships that had protected it, especially its links to the European government that provided funds to Mère et Enfant and the Palestinian National Authority. President Arafat and other prominent members of the Palestinian National Authority were dependent on the international diplomatic 
community for political and financial support. These individuals proved to be more powerful than the security forces and ensured their activities ceased.

(9) Whether aid discourses "localize" or remain "international" will depend upon the accumulation of individual strategic uses of discourse like those described here. If statements and practices converge around localization, existing aid discourses may be displaced as business rhetoric gains a greater foothold in the voluntary sector. If the events seen here are repeated elsewhere, existing aid discourses may return to dominance supported, no doubt, by stories of political corruption and the absence of democracy. More likely than either of these outcomes, however, is the continuation of discursive struggle and divergence as aid discourses remain a contested terrain.

\section{Conclusions}

Our aim in this paper has been to develop a model that does justice to the complexity of discursive activity and shows how individuals can strategically intervene in these processes. To do so, we draw on some of the extensive work that has been carried out in discourse theory and, at the same time, ground these insights in a case study that shows how discourse constituted a strategic resource in a specific situation. The model outlines the process through which discourse becomes a strategic resource. The idea of discourse as a strategic resource is composed of complex linkages that can be broken down heuristically into a set of meaningful circuits, which identify the various steps through which discourse is engaged. While the discussion focuses on the activities of the Delegate, which some might call a monological approach (Keenoy et al., 1997), it nonetheless provides 
dialogical insights into struggles for power and control among actors. Accordingly, these circuits display the power of the discourse - the ability to move specific statements from rhetoric to practice - and the limits of discursive activity.

The paper shows how the interplay between broad societal discourses, specific discursive acts, and consequential practices changed an "organization" and its "environment". We conclude that discursive activity only provides a strategic resource when appropriately grounded in the prevailing discursive context. In other words, to initiate discursive activities, actors must hold subject positions that warrant sufficient voice, as recognized by others, otherwise the impact of their activities or statements will be minimized. The symbols used must possess receptivity and be both familiar to others and capable of dislodging existing symbols. Strategy making is not just a matter of using evocative language, or getting people to think up new possibilities: talk will not turn into action unless it modifies or changes discourses, producing new concepts, objects and subject positions. Sometimes, individuals may be sufficiently creative and powerful to invent totally new concepts but, as this case suggests, they are more likely to draw on other discourses — interdiscursivity — to "borrow" concepts from elsewhere.

To conclude, this paper makes a number of contributions. First, exploring discourse as a strategic resource reveals both agency and constraint. The model takes us beyond simplistic conceptualizations that attribute excessive agency to strategic actors. It shows that discursive activities have to be located within a broader context and also that the outcomes of those activities cannot easily be controlled. Even when the discursive activity is "successful", it may set a series of 
events in train which pose other difficulties. In other words, one can dissect discourses and their effects - discourses are complex, intertwining with other discourses and diverse practices. At the same time, discourses can be employed by actors wishing to create change - their actions are not totally determined by wider discursive structures. Second, this case study gives a graphic example of how an environment and an organization can be socially enacted, and the way in which an organization is "read" read discursively by outsiders. Finally, we suggest that while our analysis focuses on the impact of discursive activity on outsiders, future studies might equally concern themselves with mapping the impact of discursive activity on members inside organizations. 


\section{Bibliography}

BARRY, D., \& ELMES, M. Strategy retold: Towards a narrative view of strategic discourse. Academy of Management Review, 1997, 22(2), 429-452.

CHAFFEE, E. E. Three models of strategy. Academy of Management Review, 1985, $10(1), 89-98$.

CLEGG, S. \& HARDY, C. Representations. In S.R. Clegg, C. Hardy, \& W.R. Nord (Eds.), Handbook of organization studies. London: Sage, 1996.

CONDOR, S., \& ANTAKI, C. Social cognition and discourse. In T. A. van Dijk (Ed.), Discourse as structure and process. London: Sage, 1997, 2, pp. 1-34.

DUTTON, J. E., \& DUKERICH, J. M. Keeping an eye on the mirror: Image and identity in organizational adaptation. Academy of Management Journal, 1991, 34(3), 517-554.

DUTTON, J. E., \& PENNER, W. J. The importance of organizational identity for strategic agenda building. In J. Hendry, G. Johnson, \& J. Newton (Eds.), Strategic thinking: Leadership and management of change. New York: John Wiley and Sons, 1993, pp. 89-113.

ECCLES, R., \& NOHRIA, N. Beyond the hype. Cambridge, Mass: Harvard Business School, 1993.

FAIRCLOUGH, N. Critical discourse analysis: Papers in the critical study of language. London: Longman, 1995.

FAIRCLOUGH, N. Discourse and social change. Cambridge: Polity Press, 1992.

FAIRCLOUGH, N., \& WODAK, R. Critical discourse analysis. In T. A. van Dijk (Ed.), Discourse as structure and process. London: Sage, 1997, 2, pp. 258-284.

FOUCAULT, M. The archeology of knowledge. London: Routledge, 1972.

GARDINER, M. The dialogics of critique. London: Routledge, 1992.

GIDDENS, A. A contemporary critique of historical materialism. London, Macmillan, 1981.

GRANT, D., KEENOY, T., \& OSWICK, C. Introduction: Organizational discourse: Of diversity, dichotomy and multi-disciplinarity. In D. Grant, T. Keenoy and C. Oswick (Eds.), Discourse and organization. London: Sage, 1998, pp. 1-13.

HAMEL, G., \& PRAHALAD, C.K. Competing for the future. Boston: Harvard Business School, 1994.

HARDY, C. \& PALMER, I. Redirections in strategy theory and practice: Walking the talk or talking the walk, Proceedings of the annual conference of ANZAM: Management theory and practice: Moving to a new era, 41-51, Melbourne: Monash University, 1997.

HARDY, C., \& PHILLIPS, N. No joking matter: Discursive struggle in the Canadian refugee system. Organization Studies, 1999, 20, 1-24.

HARDY, C., \& PHILLIPS, N. Strategies of engagement: Lessons from the critical examination of collaboration and conflict in an interorganizational domain. Organization Science, 1998, $\underline{9}, 217-230$.

HARDY, C., LAWRENCE, T., \& PHILLIPS, N. Talking action: Conversations, narrative and action in interorganizational collaboration. In D. Grant, T. 
Keenoy and C. Oswick (Eds.), Discourse and organization. London: Sage, 1998, pp. 65-83.

HARRÉ, R. Social being: A theory for social psychology. Oxford: Basil Blackwell, 1979.

HATCH, M. J. Organization theory: modern, symbolic and postmodern perspectives. Oxford: Oxford University Press, 1997.

INKPEN, A., \& CHOUDHURY, N. The seeking of strategy where it is not: Towards a theory of strategy absence. Strategic Management Journal, 1995, 16, 313323.

KEENOY, T., OSWICK, C., \& GRANT, D. Organizational discourses: Text and context. Organization, 1997, 4 (2), 147-57.

KNIGHTS, D., \& MORGAN, G. Strategic discourse and subjectivity: Towards a critical analysis of corporate strategy in organisations. Organization Studies, 1991, 12(3), 251-273.

LAWRENCE, T.B., PHILLIPS N. \& HARDY, C. Watching whale-watching: Exploring the discursive foundations of collaborative relationships. Journal of Applied Behavioral Science, forthcoming.

LYOTARD, J.-F. The postmodern condition: A report on knowledge. Manchester: Manchester University Press, 1984.

MINTZBERG, H. Strategy formation schools of thought. In J. W. Fredrickson (Ed.), Perspectives on strategic management. Greenwich, CT: JAI Press, 1990, $\underline{5}$, pp. 1-67.

MINTZBERG, $\mathrm{H}$. The rise and fall of strategic planning. Hemel Hempstead, PrenticeHall, 1994.

MUMBY, D. K., \& CLAIR, R. Organizational discourse. In T. A. van Dijk (Ed.), Discourse as structure and process. London: Sage, 1997, 2, pp. 181-205.

PALMER, I. \& HARDY, C. Thinking about management: Organizational debates in practice. London: Sage, 2000.

PALMER, I., \& DUNFORD, R. Reframing and organizational action: The unexplored link. Journal of Organizational Change Management, 1996, $\underline{9}(6), 12-25$.

PARKER, I. Discourse dynamics. London: Routledge, 1992.

PHILLIPS, N., \& HARDY, C. Managing multiple identity: Discourse, legitimacy and resources in the UK refugee system. Organization, 1997, 4(2), 159-186.

POTTER, J., \& WETHERELL, M. Discourse and social psychology: Beyond attitudes and behaviour. London: Sage, 1987.

ROULEAU, L., \& SEGUIN, F. Strategy and Organization Theories: Common Forms of Discourse. Journal of Management Studies, 1995, 32(1), 101-117.

SRIVASTVA, S., \& BARRETT, F.J. The transforming nature of metaphors in group development: A study in group theory. Human Relations, 1988, 41, 31-64.

THOMAS, P. Strategy talk: A critique of the discourse of strategic management. London: Routledge, forthcoming.

VAN DIJK, T. A. Discourse as interaction in society. In T. A. van Dijk (Ed.), Discourse as structure and process. London: Sage, 1997b, 2, pp. 1-37.

VAN DIJK, T. A. The study of discourse. In T. A. van Dijk (Ed.), Discourse as structure and process. London: Sage, 1997a, 1, pp. 1-34. 
WHIPP, R. Creative deconstruction: Strategy and organizations. In S. R. Clegg, C. Hardy and W. R. Nord (Eds.), Handbook of organization studies. London, Sage, 1996, pp. 261-275.

WHITTINGTON, R. What is strategy and does it matter? London: Routledge, 1993. ZAN, L. Looking for theories in strategy studies. Scandinavian Journal of Management, $1990 \underline{6}(2), 89-108$. 


\section{Notes}

${ }^{1}$ The authors wish to acknowledge the support of the Australian Research Council, the Social Sciences and Humanities Research Council of Canada, les Fonds pour la Formation des Chercheurs et l'Aide à la Recherche of Quebec, and McGill University in carrying out this research.

${ }^{2}$ Names have been disguised. 


\section{University Library}

\section{- M M I N E R VA A gateway to Melbourne's research publications}

Minerva Access is the Institutional Repository of The University of Melbourne

Author/s:

Hardy, C;Palmer, I;Phillips, N

Title:

Discourse as a strategic resource

Date:

2000-09-01

Citation:

Hardy, C., Palmer, I. \& Phillips, N. (2000). Discourse as a strategic resource. HUMAN RELATIONS, 53 (9), pp.1227-1248. https://doi.org/10.1177/0018726700539006.

Persistent Link:

http://hdl.handle.net/11343/116084 